\title{
PENERAPAN PENDEKATAN PEMBELAJARAN \\ MATEMATIKA REALISTIK SEBAGAI UPAYA MENINGKATKAN AKTIVITAS DAN PRESTASI BELAJAR SISWA DALAM PEMBELAJARAN BANGUN RUANG PADA SISWA KELAS IVA SDN 9 SESETAN TAHUN PELAJARAN 2011/2012
}

\author{
I Gusti Ayu Arista Widari, I Gusti Ngurah Nila Putra, I Ketut Suwija \\ Program Studi Pendidikan Matematika \\ Fakultas Keguruan Dan Ilmu Pendidikan \\ Universitas Mahasaraswati Denpasar
}

\begin{abstract}
The aim of this action research is to know whether there is an improvement in learning activity and achievement of grade IV students in learning three dimension shapesthrough the implementation of realistic approach. This research was conducted in Primary school 9 Sesetan in the academic year 2011/2012. The subjects of this study were 45 students of grade IV Primary school 9 Sesetan. The data collected in this research covered: students' learning activity which was collected from observation, and students' achievement data which was collected through some achievements test in form of objective and essay. This research was conducted in two cycles. The result of this study shows that the students' learning activity in cycle one was quite active, and in cycle two the students' learning activity was categorized as active. From the achievement of the students it was found that the average score, learning capacity, and learning outcome from the pre-cycle, cycle 1, and cycle 2 consecutively are: $4.98,49.80 \%$ and $26.67 \%$; 6.66 , $66.60 \%$ and $53.30 \%$; then $8.20,82 \%$ and $91.10 \%$. From the result of data analysis and discussion, then it can be concluded that there is an improvement in terms of students' learning activity and achievement of IV grade students of Primary school 9 Sesetan in the academic year 2011/2012 in learning three dimension shapes through the use of realistic approach.
\end{abstract}

Key words: learning activity, achievement, realistic approach

\section{PENDAHULUAN}

Pendidikan

merupakan

kebutuhan sepanjang hayat, setiap manusia membutuhkan pendidikan sampai kapanpun dan dimanapun ia berada. Pendidikan sangat penting bagi manusia, sebab tanpa pendidikan manusia akan sulit berkembang. Sekolah sebagai pelaksana lembaga pendidikan formal terdiri atas pendidikan dasar, pendidikan menengah dan 
pendidikan tinggi, yang berfungsi untuk meneruskan nilai-nilai luhur bangsa pada generasi muda. Pendidikan juga merupakan salah satu upaya untuk meningkatkan kualitas sumber daya manusia (SDM) baik fisik, mental maupun spiritual.

Dalam proses belajar mengajar di sekolah, siswa mempelajari beberapa bidang studi termasuk matematika. Matematika mempunyai peranan yang sangat

penting dalam kehidupan sehari-hari maupun dalam membantu bidang ilmu lainnya. Mengingat pentingnya peranan matematika, timbul harapan agar prestasi belajar matematika dapat ditingkatkan. Tetapi dalam kenyataan menunjukkan prestasi belajar matematika siswa masih tergolong rendah. Berbagai upaya telah dilakukan, dan berbagai metode pembelajaran telah dicobakan, namun hasil yang diperoleh belum optimal sesuai dengan yang diharapkan. Hal ini disebabkan karena masih banyaknya anggapan siswa yang kurang positif terhadap matematika.
Sekolah dasar merupakan lembaga pertama bagi peserta didik untuk belajar membaca, menulis dan berhitung. Kemampuan berhitung di sekolah dasar memiliki beberapa tujuan diantaranya menanamkan dan meletakkan landasan berhitung yang kuat untuk mempelajari pengetahuan tentang matematika, disamping kemampuan dalam memecahkan masalah. Untuk mengatasi masalah pembelajaran di sekolah dasar berbagai pakar pendidikan matematika menyarankan agar siswa diarahkan mempelajari matematika dalam konteks dimana siswa dapat melihat penerapan matematika dalam situasi nyata. Oleh karena, itu siswa tidak akan merasa asing dengan matematika dan sedikit demi sedikit siswa akan menyukai matematika.

Salah satu materi yang diajarkan di sekolah dasar adalah bangun ruang. Pembelajaran bangun ruang di sekolah dasar cenderung berorientasi pada guru. Guru jarang memulai pelajarannya dengan masalah nyata mengenai bangun ruang, yang kemudian diarahkan pada penemuan konsep, prosedur matematika, dan prinsip bangun 
ruang itu sendiri. Akibat dari pembelajaran tersebut adalah siswa kurang mampu dalam penalaran bangun ruang.

Berdasarkan hasil wawancara dengan guru matematika kelas IVA SDN 9 Sesetan yang dilakukan pada tanggal 17 Januari 2012, diperoleh data bahwa rata-rata skor untuk mata pelajaran matematika siswa kelas IVA SDN 9 Sesetan dalam tes sumatif pada semester I tahun 2012 yaitu 6,25. Ini menunjukan bahwa pretasi belajar siswa masih tergolong rendah, karena rata-rata skor masih di bawah standar minimal yaitu 6,5. Setelah kegiatan wawancara dilakukan pengamatan terhadap kegiatan pembelajaran matematika di kelas IVA. Selama kegiatan pengamatan di kelas berlangsung, diduga bahwa penyebab rendahnya prestasi belajar siswa adalah guru dalam mengajar cenderung menggunakan metode konvensional, siswa terlihat pasif, guru jarang memposisikan pembelajaran ke dalam suatu konteks atau pembelajaran yang menggunakan permasalahan realistik, sehingga siswa kurang mampu membayangkan konsep yang sedang dibahas.

Sehubungan dengan itu, alternatif pendekatan yang dipandang sesuai diterapkan untuk mengatasi masalah tersebut adalah pendekatan pembelajaran matematika realistik (PMR). Dalam pendekatan ini, siswa diberikan kesempatan sendiri untuk menemukan ide maupun konsepkonsep, dimana dalam konsep ini diawali dengan masalah realistik. Suatu masalah realistik tidak harus selalu berupa masalah yang ada di dunia nyata dan bisa ditemukan dalam kehidupan sehari-hari siswa, namun suatu masalah disebut realistik jika masalah tersebut dapat dibayangkan atau nyata dalam pikiran siswa. Dalam pembelajaran matematika realistik, permasalahan realistik digunakan sebagai fondasi dalam membangun konsep matematika, kemudian definisi akhir, sifat dan teorema dapat ditemukan. Untuk hal tersebut siswa diharapkan lebih aktif berdiskusi dan melakukan refleksi agar dapat mengkonstruksi konsep-konsep matematika. Dengan menerapkan pendekatan pembelajaran matematika realistik 
akan dapat menimbulkan semangat, gairah dan percaya diri dalam belajar sehingga dapat meningkatkan prestasi belajar siswa.

Fokus dalam penelitian ini adalah penerapan pendekatan pembelajaran matematika realistik sebagai upaya meningkatkan aktivitas dan prestasi belajar siswa dalam pembelajaran bangun ruang pada siswa kelas IVA SDN 9 Sesetan Tahun Pelajaran 2011/2012. Permasalahan yang ingin dicari jawabannya dalam penelitian ini adalah (1) apakah terjadi peningkatan aktivitas belajar siswa kelas IVA SDN 9 Sesetan Tahun Pelajaran 2011/2012 dalam pembelajaran bangun ruang melalui penerapan pendekatan pembelajaran matematika realistik, apakah terjadi peningkatan prestasi belajar siswa kelas IVA SDN 9 Sesetan tahun pelajaran 2011/2012 dalam pembelajaran bangun ruang melalui penerapan pendekatan pembelajaran matematika realistik.

Berdasarkan fokus penelitian dan rumusan masalah tersebut, maka tujuan penelitian ini adalah: (1) untuk mengetahui apakah terjadi peningkatkan aktivitas belajar siswa kelas IVA SDN 9 Sesetan tahun pelajaran 2011/2012 dalam pembelajaran bangun ruang melalui penerapan pendekatan pembelajaran matematika realistik, dan (2) untuk mengetahui apakah terjadi peningkatkan prestasi belajar siswa kelas IVA SDN 9 Sesetan tahun pelajaran 2011/2012 dalam pembelajaran bangun ruang melalui penerapan pendekatan pembelajaran matematika realistik.

Treffers (dalam Wijaya, 2012:21) menyatakan bahwa pembelajaran matematika realistik adalah pendekatan pembelajaran yang menggunakan permasalahan realistik sebagai fondasi dalam membangun konsep matematika. Senada dengan hal tersebut, Soedjadi (2001:2) mengemukakan "pembelajaran matematika realistik (PMR) pada dasarnya adalah pemanfaatan realitas dan lingkungan yang dipahami peserta didik untuk memperlancar proses pembelajaran matematika, sehingga dapat mencapai tujuan pendidikan matematika secara lebih baik dari masa yang lalu." Sesuai dengan 
uraian di atas, maka pendekatan pembelajaran matematika realistik adalah suatu pedomanbagi pendidik dalam membangun konsep matematika dengan menempatkan realitas dan lingkungan peserta didik sebagai sumber .

Wijaya

menyatakan "suatu masalah disebut realistik jika masalah tersebut dapat dibayangkan (imagineable) atau nyata (real) dalam pikiran

Siswa." Pendekatan realistik adalah suatu pendekatan yang menggunakan masalah realistik sebagai tolak pangkal pembelajaran. Diawali dengan aktivitas mematisasi konsepkonsep yang dipelajari siswa. Treffers (dalam Wijaya, 2012:42) membagi matematisasi menjadi dua, yaitu: (1) matematisasi horizontal, yaitu diawali dengan mengidentifikasi konsep matematika berdasarkan keteraturan dan hubungan yang ditemukan melalui visualisasi dan skematisasi masalah, (2) matematisasi vertikal, yaitu bentuk proses formalisasi di mana model matematika yang diperoleh pada matematisasi horizontal menjadi landasan dalam pengembangan konsep matematika yang lebih formal.

Treffers (dalam Suharta, 2001:3) menyebutkan bahwa karakteristik dari pembelajaran matematika realistik yaitu: menggunakan dunia nyata, pembelajaran diawali dengan masalah kontekstual (dunia nyata) sehingga memungkinkan siswa menggunakan pengalaman sebelumnya secara langsung untuk menemukan suatu konsep. Melalui abstraksi dan formalisasi, siswa dapat mengembangkan konsep yang lebih komplit. Kemudian siswa dapat mengaplikasikan konsep-konsep matematika kedalam bidang yang lain ataupun dunia nyata sehingga memperkuat pemahaman konsep, (2) penggunaan model, istilah model berkaitan dengan situasi dan model matematika yang dikembangkan sendiri oleh siswa (self developed models). Peran self developed models merupakan jembatan bagi siswa dari situasi konkret menuju abstrak atau konteks informal ke formal dimana siswa membuat model sendiri dalam menyelesaikan masalah sehingga diperoleh pengetahuan matematika 
formal (bersifat abstrak), (3) menggunakan produksi dan konstruksi oleh siswa, siswa mempunyai kesempatan untuk mengembangkan strategi-strategi informal pemecahan masalah yang dapat mengarah pada konstruksi prosedur-prosedur pemecahan masalah. Dengan bimbingan guru, siswa diharapkan menemukan kembali konsep dalam bentuk formal, (4) menggunakan interaktif, interaksi antara siswa dan guru merupakan hal mendasar dalam pembelajaran matematika realistik. Secara eksplisit bentuk-bentuk interaksi yang berupa negosiasi, penjelasan, pembenaran, setuju, tidak setuju, pertanyaan atau refleksi digunakan untuk mencapai bentuk formal dari bentuk-bentuk informal siswa, (5) keterkaitan unit belajar (intertwinement), dalam pembelajaran matematika realistik, keterkaitan unit-unit matematika adalah esensial. Dengan keterkaitan ini akan memudahkan siswa dalam proses pemecahan masalah.

Menurut Gravemeijer (dalam Lemik, 2010:25) ada tiga prinsip utama dalam pembelajaran berdasarkan pendekatan pembelajaran matematika realistik yaitu: (1) guided reinvention (menemukan kembali) and progressive mathematizing (matematika progresif), peserta harus diberikan kesempatan untuk mengalami proses yang sama sebagaimana konsep-konsep matematika ditemukan. Pembelajaran dimulai dengan suatu masalah kontekstual atau realistik yang selanjutnya melalui aktivitas siswa diharapkan menemukan kembali sifat, definisi, teorema atau prosedur-prosedur. Masalah kontekstual yang dipilih mempunyai berbagai kemungkinan solusi. Perbedaan penyelesaian atau prosedur siswa dalam memecahkan masalah dapat digunakan sebagai langkah proses matematisasi baik horizontal maupun vertikal, (2) didactical phenomenology (fenomena didaktik), situasi-situasi yang diberikan dalam suatu topik matematika disajikan atas dua pertimbangan, yaitu melihat kemungkinan aplikasi dalam pengajaran dan sebagai titik tolak dalam proses mematematisasi. 
Tujuan penyelidikan fenomenafenomena tersebut adalah untuk menemukan situasi-situasi masalah khusus yang dapat digeneralisasikan dan dapat digunakan sebagai dasar matematisasi vertikal, dan (3) selfdeveloped model (pengembangan model sendiri), kegiatan ini berperan sebagai jembatan antara pengetahuan formal dan matematika formal. Model dibuat siswa sendiri dalam memecahkan masalah. Model pada awalnya adalah suatu model dari situasi yang dikenal (akrab) dengan siswa. Dengan suatu proses generalisasi dan formalisasi, model tersebut akhirnya menjadi suatu penalaran matematika.

Pembelajaran Matematika

Realistik memiliki langkah-langkah pembelajaran. Adapun langkahlangkah Pembelajaran Matematika Realistik mengacu pada Suharta (2001). Berdasarkan pendapat tersebut di atas, pada dasarnya pengajaran dengan menggunakan pendekatan pembelajaran matematika realistik dicirikan oleh: (1) matematika dipandang sebagai kegiatan manusia sehari-hari, sehingga untuk memecahkan masalah-masalah dalam kehidupan sehari-hari, (2) belajar matematika berarti bekerja dengan matematika, (3) siswa diberikan kesempatan untuk menemukan konsep-konsep matematika dibawah bimbingan orang dewasa (guru), (4) proses belajar mengajar berlangsung secara interaktif, dan siswa menjadi fokus dari semua aktifitas di dalam kelas, dan (5) aktifitas yang dilakukan meliputi: menemukan masalah kontekstual, memecahkan masalah, dan mengorganisasi bahan ajar.

\section{METODE PENELITIAN}

\section{Pendekatan dan Jenis Penelitian}

Penelitian ini menggunakan pendekatan kualitatif. Penelitian kualitatif merupakan penelitian yang dilakukan pada latar alamiah atau pada konteks dari suatu keutuhan (entity) dengan memanfaatkan diri peneliti sebagai instrumen kunci, Moleong (2011:8).

Jenis penelitian ini adalah Penelitian Tindakan Kelas (PTK) atau classroom action research. Desain atau model PTK yang digunakan dalam penelitian tindakan kelas ini adalah desain PTK model 
Kurt Lewin yang mengandung empat komponen pada setiap siklus. Keempat komponen tersebut meliputi: (1) perencanaan (planning) yaitu rencana tindakan yang akan dilakukan untuk memperbaiki, meningkatkan atau perubahan perilaku dan sikap sebagai pemecahan masalahnya, (2) tindakan (action) yaitu sesuatu yang dilakukan guru atau peneliti sebagai upaya perbaikan, peningkatan, atau perubahan yang diinginkan, (3) pengamatan (observing) yaitu mengamati hasil atau dampak dari tindakan yang dilaksanakan atau dikenakan kepada siswa, dan (4) refleksi (reflecting) yaitu peneliti mengkaji, melihat dan mempertimbangkan atas hasil atau dampak dari tindakan yang nantinya akan direvisi terhadap rencana sebelumnya (Suandhi, 2006:16).

\section{Tempat dan Subjek Penelitian}

Penelitian ini dilaksanakan di SDN 9 Sesetan. Subjek penelitian ini adalah siswa kelas IVA SDN 9 Sesetan tahun pelajaran 2011/2012, sebanyak 45 orang yang terdiri dari 24 siswa putra dan 21 siswa putri.

\section{Data dan Sumber Data}

Data yang dikumpulkan difokuskan untuk menjawab masalah yang dirumuskan dalam penelitian ini berupa skor dan catatan lapangan. Skor dalam penelitian ini terdiri dari skor aktivitas belajar siswa dan skor prestasi belajar siswa. Sumber data dalam penelitian ini menitik beratkan pada manusia, yaitu siswa kelas IVA SDN 9 Sesetan.

\section{Teknik Pengumpulan Data}

Data yang dikumpulkan dalam penelitian ini meliputi data aktivitas belajar

siswa dan data prestasi belajar siswa. Data aktivitas belajar siswa dikumpulkan dengan teknik observasi. Instrumen yang digunakan berupa lembar observasi yang memuat indikator-indikator aktivitas yang harus diamati pada masingmasing siswa. Adapun indikatorindikator aktivitas belajar siswa tersebut adalah: (1) antusiasme siswa dalam proses pembelajaran, (2) interaksi siswa dengan guru, (3) interaksi siswa dengan siswa, (4) usaha siswa dalam mengerjakan soal, (5) partisipasi siswa dalam 
menyimpulkan materi pelajaran. analisis statistik deskriptif dan Dalam setiap indikator memuat 4 digolongkan berdasarkan kriteria dari deskriptor.

Adapun cara pemberian skor tentang aktivitas belajar siswa adalah sebagai berikut. Dalam lembar observasi memuat 5 indikator dan setiap indikator memuat 4 deskriptor. Setiap deskriptor dari masing-masing indikator aktivitas belajar siswa yang tampak selama proses pembelajaran dicatat pada lembar observasi dengan memberi tanda rumput $(\sqrt{ })$. Jika sebuah deskriptor tampak maka diberi skor 1 dan jika tidak nampak diberi skor 0 . Sehingga skor maksimal ideal aktivitas

belajar siswa adalah 20 dan skor minimal ideal adalah 0 .

Data prestasi belajar siswa dikumpulkan dengan teknik tes. Instrumen yang dipakai dalam pengumpulan data ini menggunakan tes prestasi belajar yang berupa tes objektif dan tes uraian (essay) yang diberikan pada akhir masing-masing siklus.

\section{Teknik Analisis Data}

Nurkancana dan Sunartana (1992:100). Untuk mengetahui prestasi belajar siswa, maka hasil tes prestasi belajar siswa dianalisis dengan mencari rata-rata skor prestasi belajar siswa atau mean, ketuntasan belajar siswa dan daya serap. Hasil perhitungan rata-rata skor prestasi belajar siswa $(\overline{\mathrm{X}})$, ketuntasan belajar siswa (KB), dan daya serap (DS) selanjutnya dikomparasikan dengan standar acuan yang ditetapkan Depdikbud (dalam Widiyanti, 2009:21), yaitu proses pembelajaran telah optimaljika rata-rata skor prestasi belajar siswa $(\overline{\mathrm{X}}) \geq 6,5$, daya serap $(D S) \geq 65 \%$ dan ketuntasan belajar siswa $(\mathrm{KB}) \geq 85 \%$.

\section{Prosedur Penelitian}

Penelitian ini adalah Penelitian Tindakan Kelas (PTK) yang direncanakan

dalam dua siklus. Masing-masing siklus terdiri empat komponen, yaitu:

(1) perencanaan (planning),

Data aktivitas belajar siswa tindakan (acting), (3) pengamatan dianalisis dengan menggunakan 
(observing), dan (4) refleksi (reflecting).

model pembelajaran yang membuat siswa menjadi aktif dan tidak bosan dalam mengikuti pelajaran

\section{Refleksi Awal}

Berdasarkan hasil wawancara dengan guru matematika kelas IVA SDN 9 Sesetan yang dikakukan pada tanggal 17 Januari 2012, diperoleh data bahwa rata-rata skor untuk mata pelajaran matematika siswa kelas IVA SDN 9 Sesetan dalam tes sumatif pada semester I tahun 2012 yaitu 6,25. Ini menunjukan bahwa pretasi belajar siswa masih tergolong rendah karena nilai rata-rata masih di bawah standar minimal yaitu 6,5 . Setelah kegiatan wawancara dilakukan pengamatan terhadap kegiatan pembelajaran matematika di kelas IVA, diduga bahwa penyebab rendahnya prestasi belajar siswa adalah sebagai berikut: (1) guru dalam mengajar cenderung menggunakan metode konvensional, (2) siswa pasif, dan (3) guru jarang memposisikan pembelajaran ke dalam suatu konteks atau pembelajaran yang menggunakan permasalahan realistik.

Berdasarkan situasi tersebut, maka perlu diterapkannya suatu matematika khususnya pembelajaran bangun ruang. Pendekatan yang diduga tepat digunakan adalah pembelajaran matematika realistik. Dalam pembelajaran matematika realistik menuntut aktivitas siswa secara optimal. Selain itu, pendekatan pembelajaran matematika realistik selalu mengaitkan pengalaman siswa sehari-hari di dalam proses pembelajaran. Terlebih lagi pembelajaran bangun ruang masih bersifat abstrak bagi siswa sekolah dasar. Oleh karena itu dengan pendekatan pembelajaran matematika realistik yang mengaitkan kehidupan nyata siswa dengan sifat abstrak bangun ruang, maka proses pembelajaran akan menjadi menarik dan menyenangkan.

\section{Siklus I}

Siklus I dilaksanakan dalam 3 kali pertemuan dengan rincian dua kali pertemuan untuk pelaksanaan tindakan dan satu kali pertemuan untuk melakukan tes prestasi belajar. 
Siklus I terdiri dari empat komponen meliputi: perencanaan,

pelaksanaan, observasi atau evaluasi, dan refleksi.

\section{Perencanaan Tindakan.}

Sesuai dengan permasalahan yang muncul pada refleksi awal maka akan diterapkan pendekatan pembelajaran matematika realistik dalam pembelajaran bangun bangun ruang. Selanjutnya, ada beberapa hal yang perlu dipersiapkan dalam siklus ini sebagai berikut: (1) menyusun rencana pelaksanaan pembelajaran (RPP) yang mengacu pada langkahlangkah Pembelajaran Matematika Realistik (2) membuat lembar kerja siswa (LKS), (3) membuat tes prestasi belajar, (4) membuat lembar observasi, (5) membuat buku catatan lapangan.

\section{Pelaksanaan}

Tindakan.

Berdasarkan perencanaan tindakan di atas, pada komponen ini peneliti melaksanakan penerapan pendekatan pembelajaran matematika realistik dalampembelajaran bangun ruang. Pada pertemuan pertama materi yang akan dibahas adalah sifat-sifat bangun ruang sederhana. Adapun yang di bahas meliputi sifat-sifat kubus dan balok, serta cara menggambar kubus dan balok berdasarkan sifat-sifatnya. Langkahlangkah pembelajarannya adalah sebagai berikut.

Tabel 01 Langkah-langkah Pembelajaran Pertemuan 1 Siklus I

\begin{tabular}{|l|l|}
\hline \multicolumn{2}{|c|}{ Pendahuhuan } \\
\hline \multicolumn{1}{|c|}{ Kegiatan Guru } & \multicolumn{1}{c|}{ Kegiatan Siswa } \\
\hline $\begin{array}{l}\text { 1. Melakukan absensi. } \\
\begin{array}{l}\text { 2. Mengingatkan kembali materi } \\
\text { pembelajaran sebelumnya. }\end{array}\end{array}$ & $\begin{array}{l}\text { 1. Mendengarkan guru dan } \\
\text { mengucapkan kata hadir. } \\
\text { 2. Berusaha mengingat kembali materi } \\
\text { pelajaran sebelumnya. }\end{array}$ \\
$\begin{array}{l}\text { 3. Menyampaikan tujuan pembelajaran. } \\
\text { 3endengarkan tujuan pembelajaran } \\
\text { yang ingin dicapai. }\end{array}$ \\
\hline \multicolumn{2}{|c|}{ Kegiatan Inti } \\
\hline $\begin{array}{l}\text { 1. Meminta siswa mengingat benda- } \\
\text { benda yang menyerupai kubus dn } \\
\text { balok sesuai pengalaman mereka } \\
\text { masing-masing. }\end{array}$ & $\begin{array}{l}\text { 1. Secara mandiri mengingat benda- } \\
\text { benda yang menyerupai kubus dan } \\
\text { balok. }\end{array}$ \\
$\begin{array}{l}\text { 2. Memberi kesempatan kepada siswa } \\
\text { untuk membayangkan sifat-sifat } \\
\text { bangun ruang tersebut serta cara } \\
\text { menggambarnya sesuai dengan }\end{array}$ & $\begin{array}{l}\text { 2. Menggunakan strategi yang paling } \\
\text { efektif sesuai pengalamannya } \\
\text { masing-masing. }\end{array}$ \\
\hline
\end{tabular}


strategi mereka masing-masing.

3. Memberikan siswa beberapa masalah sehari-hari yang berkaitan dengan kubus dan balok, selanjutnya siswa mengerjakan masalah dengan menggunakan pengalaman mereka.

4. Mendekati siswa sambil memberikan bantuan seperlunya.

5. Menjelaskan secara formal sifat-sifat kubus dan balok serta cara menggambarnya.

6. Membagikan LKS

7. Memberikan kesempatan kepada siswa untuk mengerjakan kedepan sesuai jawaban mereka masingmasing.

8. Memberikan tugas di rumah yaitu mengerjakan soal-soal serta jawabannya sesuai dengan matematika formal.
3. Secara sendiri-sendiri atau berkelompok menyelesaikan masalah tersebut.

4. Meminta bantuan kepada guru atau teman sekelas apabila mengalami kesulitan dan melalui diskusi kelas, jawaban siswa dikonfrontasikan.

5. Mendengarkan dan merumuskan bentuk matematika formal, yaitu bentuk matematika yang sering digunakan dalam proses pembelajaran di kelas.

6. Mengerjakan soal-soal dalam LKS

7. Beberapa siswa maju kedepan untuk menjawab soal.

8. Mengerjakan tugas rumah dan menyerahkannya kepada guru pada pertemuan selanjutnya.

\begin{tabular}{|l|l|}
\hline \multicolumn{2}{|c|}{ Penutup } \\
\hline \multicolumn{1}{|c|}{ Kegiatan Guru } & \multicolumn{1}{c|}{ Kegiatan Siswa } \\
\hline $\begin{array}{l}\text { 1. Bersama-sama menyimpulkan materi } \\
\text { pelajaran yang baru diberikan. }\end{array}$ & $\begin{array}{l}\text { 1. Bersama-sama menyimpulkan } \\
\text { materi pelajaran yang baru } \\
\text { diberikan. }\end{array}$ \\
\hline
\end{tabular}

Pada pertemuan kedua materi yang akan dibahas meliputi sifat-sifat tabung, kerucut dan bola, serta cara menggambar tabung, kerucut dan bola berdasarkan sifat-sifatnya. Adapun langkah-langkah pembelajarannya adalah sebagai berikut.

Tabel 02 Langkah-langkah Pembelajaran Pertemuan 2 Siklus I.

\begin{tabular}{|l|l|}
\hline \multicolumn{2}{|c|}{ Pendahuluan } \\
\hline \multicolumn{1}{|c|}{ Kegiatan Guru } & \multicolumn{1}{c|}{ Kegiatan Siswa } \\
\hline 1. Melakukan absensi. & $\begin{array}{l}\text { 1. Mendengarkan guru dan } \\
\text { mengucapkan kata hadir. }\end{array}$ \\
$\begin{array}{l}\text { 2. Mengingatkan kembali materi } \\
\text { pembelajaran sebelumnya. }\end{array}$ & $\begin{array}{l}\text { 2. Berusaha mengingat kembali materi } \\
\text { pelajaran sebelumnya. }\end{array}$ \\
$\begin{array}{l}\text { 3. Menyampaikan tujuan pembelajaran. } \\
\text { 3endengarkan tujuan pembelajaran } \\
\text { yang ingin dicapai. }\end{array}$ \\
\hline
\end{tabular}




\begin{tabular}{|c|c|}
\hline \multicolumn{2}{|c|}{ Kegiatan Inti } \\
\hline Kegiatan Guru & Kegiatan Siswa \\
\hline $\begin{array}{l}\text { 1. Meminta siswa mengingat benda- } \\
\text { benda yang menyerupai tabung, } \\
\text { kerucut, dan bola sesuai pengalaman } \\
\text { mereka masing-masing. } \\
\text { 2. Memberi kesempatan kepada siswa } \\
\text { untuk mengingat sifat-sifat bangun } \\
\text { ruang tersebut, dan membayangkan } \\
\text { cara menggambarnya sesuai dengan } \\
\text { strategi mereka masing-masing. }\end{array}$ & $\begin{array}{l}\text { 1. Secara mandiri mengingat benda- } \\
\text { benda yang menyerupai menyerupai } \\
\text { tabung, kerucut, dan bola } \\
\text { 2. Menggunakan strategi yang paling } \\
\text { efektif sesuai pengalamannya } \\
\text { masing-masing. }\end{array}$ \\
\hline $\begin{array}{l}\text { 3. Mendekati siswa sambil memberikan } \\
\text { bantuan seperlunya. }\end{array}$ & $\begin{array}{l}\text { 3. Meminta bantuan kepada guru atau } \\
\text { teman sekelas apabila mengalami } \\
\text { kesulitan dan melalui diskusi kelas, } \\
\text { jawaban siswa dikonfrontasikan. }\end{array}$ \\
\hline $\begin{array}{l}\text { 4. Menjelaskan secara formal sifat-sifat } \\
\text { tabung, kerucut dan bola, serta cara } \\
\text { menggambarnya sesuai dengan sifat } \\
\text { masing-masing. }\end{array}$ & $\begin{array}{l}\text { 4. Mendengarkan dan merumuskan } \\
\text { bentuk matematika formal, yaitu } \\
\text { bentuk matematika yang sering } \\
\text { digunakan dalam proses }\end{array}$ \\
\hline 5. Membagikan LKS & pembelajaran di kelas. \\
\hline $\begin{array}{l}\text { 6. Memberikan kesempatan kepada } \\
\text { siswa untuk mengerjakan kedepan } \\
\text { sesuai jawaban mereka masing- } \\
\text { masing. }\end{array}$ & $\begin{array}{l}\text { 5. Mengerjakan soal-soal dalam LKS } \\
\text { 6. Beberapa siswa maju kedepan } \\
\text { untuk menjawab soal. }\end{array}$ \\
\hline $\begin{array}{l}\text { 7. Memberikan tugas di rumah yaitu } \\
\text { mengerjakan soal-soal serta } \\
\text { jawabannya sesuai dengan } \\
\text { matematika formal. }\end{array}$ & $\begin{array}{l}\text { 7. Mengerjakan tugas rumah dan } \\
\text { menyerahkannya kepada guru pada } \\
\text { pertemuan selanjutnya. }\end{array}$ \\
\hline \multicolumn{2}{|c|}{ Penutup } \\
\hline Kegiatan Guru & Kegiatan Siswa \\
\hline $\begin{array}{l}\text { 1. Bersama-sama menyimpulkan materi } \\
\text { pelajaran yang baru diberikan. }\end{array}$ & $\begin{array}{l}\text { 1. Bersama-sama menyimpulkan } \\
\text { materi pelajaran yang baru } \\
\text { diberikan. }\end{array}$ \\
\hline
\end{tabular}

Observasi. Kegiatan observasi dilaksanakan selama proses pembelajaran berlangsung. Observasi terhadap aktivitas belajar siswa dilakukan dengan mengamati perilaku yang tampak menggunakan lembar observasi. Sedangkan observasi terhadap prestasi belajar siswa

dilakukan dengan menggunakan tes berupa tes objektif dan tes uraian yang dilaksanakan pada akhir siklus I.

Refleksi. Tahap refleksi dilakukan pada akhir siklus I yang didasarkan pada hasil observasi, evaluasi selama proses pembelajaran 
dan catatan lapangan. Refleksi ini dilakukan oleh peneliti dengan tujuan untuk mengidentifikasi dampak tindakan pada siklus I, sejauh mana hasil yang dicapai, kelemahan serta kendala yang dialami. Permasalahan yang timbul selama pembelajaran siklus I didiskusikan dengan teman sejawat serta guru kelas dan dicari alternatif pemecahannya. Selain itu, refleksi dijadikan sebagai masukan untuk menyempurnakan pembelajaran pada siklus siklus II sehingga kelemahankelemahan pada siklus I dapat diatasi.

\section{Siklus II}

Siklus II dilaksanakan jika hasil yang diperoleh pada siklus I belum sesuai dengan yang diharapkan. Siklus II dilaksanakan dalam 3 kali pertemuan dengan rincian dua kali pertemuan untuk pelaksanaan tindakan dan satu kali pertemuan untuk melakukan tes prestasi belajar. Adapun langkahlangkahnya yang diambil serupa dengan siklus I yaitu, perencanaan, pelaksanaan, observasi dan refleksi. Namun demikian langkah- langkahnya

merupakan penyempurnaan dari langkahlangkah pada siklus I.

\section{Perencanaan}

Tindakan.

Dalam perencanaan pada diklus II ini peneliti menyiapkan hal-hal yang hampir sama pada siklus I yaitu: (1) menyusun rencana pelaksanaan pembelajaran (RPP) yang mengacu pada langkah-langkah pembelajaran matematika realistik, (2) membuat lembar kerja siswa (LKS), (3) membuat tes prestasi belajar, (4) membuat lembar observasi, (5) membuat buku catatan lapangan.

\section{Pelaksanaan}

Tindakan.

Berdasarkan perencanaan tindakan di atas, pada komponen ini peneliti melaksanakan penerapan pendekatan pembelajaran matematika realistik dalam pembelajaran bangun ruang. Pada pertemuan ini materi yang akan dibahas adalah menggambar dan mengidentifikasi jaring-jaring kubus. Adapun langkah-langkah pembelajarannya adalah sebagai berikut. 
Tabel 03 Langkah-langkah Pembelajaran Pertemuan 1 Siklus II

\begin{tabular}{|c|c|}
\hline \multicolumn{2}{|c|}{ Pendahuluan } \\
\hline Kegiatan Guru & Kegiatan Siswa \\
\hline $\begin{array}{l}\text { 1. Melakukan absensi. } \\
\text { 2. Mengingat kembali materi } \\
\text { pembelajaran sebelumnya. } \\
\text { 3. Menyampaikan tujuan } \\
\text { pembelajaran. }\end{array}$ & $\begin{array}{l}\text { 1. Mendengarkan guru dan } \\
\text { mengucapkan kata hadir } \\
\text { 2. Berusaha mengingat kembali materi } \\
\text { pelajaran sebelumnya. } \\
\text { 3. Mendengarkan tujuan pembelajaran } \\
\text { yang ingin dicapai. }\end{array}$ \\
\hline \multicolumn{2}{|c|}{ Kegiatan Inti } \\
\hline Kegiatan Guru & Kegiatan Siswa \\
\hline $\begin{array}{l}\text { 1. Meminta siswa menyebutkan } \\
\text { contoh benda-benda dalam } \\
\text { kehidupan sehari yang bentuknya } \\
\text { menyerupai kubussesuai dengan } \\
\text { pengalaman mereka masing- } \\
\text { masing. } \\
\text { 2. Menunjukkan kepada siswa alat } \\
\text { peraga berupa benda berbentuk } \\
\text { kubus, seperti: kotak kapur dan } \\
\text { kotak biscuit. } \\
\text { 3. Menggunting kotak kapur dan } \\
\text { kotak biscuit sehingga nampak } \\
\text { jaring-jaring kubus kemudian } \\
\text { ditempel pada papan tulis. } \\
\text { 4. Meminta siswa untuk menggambar } \\
\text { jaring-jaring kubus secara mandiri } \\
\text { sesuai dengan strategi masing- } \\
\text { masing. } \\
\text { 5. Mendekati siswa sambil } \\
\text { memberikan bantuan seperlunya. } \\
\text { 6. Menjelaskan secara formal cara } \\
\text { menggambar dan mengidentifikasi } \\
\text { jaring-jaring kubus } \\
\text { 7. Membagikan LKS } \\
\text { 8. Memberikan kesempatan kepada } \\
\text { siswa untuk mengerjakan ke depan } \\
\text { sesuai jawaban mereka masing- } \\
\text { masing. } \\
\text { 9. Memberikan tugas di rumah yaitu } \\
\text { mengerjakan soal-soal serta } \\
\text { jawabannya sesuai dengan } \\
\text { matematika formal. }\end{array}$ & $\begin{array}{l}\text { 4. Mengerjakannya secara mandiri } \\
\text { sesuai dengan strategi masing- } \\
\text { masing. } \\
\text { 5. Meminta bantuan kepada guru atau } \\
\text { teman apabila mengalami kesulitan. } \\
\text { 6. Mendengarkan dan merumuskan } \\
\text { bentuk matematika formal, yaitu } \\
\text { bentuk matematika yang sering } \\
\text { digunakan dalam proses } \\
\text { pembelajaran di kelas. } \\
\text { 7. Mengerjakan soal-soal dalam LKS. } \\
\text { 8. Beberapa siswa maju ke depan untuk } \\
\text { menjawab soal. } \\
\text { 9. Mengerjakan tugas rumah dan } \\
\text { menyerahkannya kepada guru pada } \\
\text { pertemuan selanjutnya. }\end{array}$ \\
\hline
\end{tabular}




\begin{tabular}{|c|c|}
\hline \multicolumn{2}{|c|}{ Penutup } \\
\hline \multicolumn{1}{|c|}{ Kegiatan Guru } & \multicolumn{1}{c|}{ Kegiatan Siswa } \\
\hline $\begin{array}{l}\text { 1. Bersama-sama menyimpulkan } \\
\text { materi pelajaran yang baru } \\
\text { diberikan. }\end{array}$ & $\begin{array}{l}\text { 1. Bersama-sama menyimpulkan } \\
\text { materi pelajaran yang baru } \\
\text { diberikan. }\end{array}$ \\
\hline \\
Pada pertemuan kedua materi & jaring-jaring balok. Adapun \\
yang akan dibahas adalah $\quad$ langkah-langkah pembelajarannya \\
menggambar dan mengidentifikasi adalah sebagai berikut. \\
Tabel 04 Langkah-langkah Pembelajaran Pertemuan 2 Siklus II
\end{tabular}

\begin{tabular}{|c|c|}
\hline \multicolumn{2}{|c|}{ Pendahuluan } \\
\hline Kegiatan Guru & Kegiatan Siswa \\
\hline $\begin{array}{l}\text { 1. Melakukan absensi. } \\
\text { 2. Mengingat kembali materi } \\
\text { pembelajaran sebelumnya. } \\
\text { 3. Menyampaikan tujuan } \\
\text { pembelajaran. }\end{array}$ & $\begin{array}{l}\text { 1. Mendengarkan guru dan } \\
\text { mengucapkan kata hadir } \\
\text { 2. Berusaha mengingat kembali materi } \\
\text { pelajaran sebelumnya. } \\
\text { 3. Mendengarkan tujuan pembelajaran } \\
\text { yang ingin dicapai. }\end{array}$ \\
\hline \multicolumn{2}{|c|}{ Kegiatan Inti } \\
\hline Kegiatan Guru & Kegiatan Siswa \\
\hline $\begin{array}{l}\text { 1. Meminta siswa menyebutkan } \\
\text { contoh benda-benda dalam } \\
\text { kehidupan sehari yang bentuknya } \\
\text { menyerupai baloksesuai dengan } \\
\text { pengalaman mereka masing- } \\
\text { masing. } \\
\text { 2. Menunjukkan kepada siswa alat } \\
\text { peraga berupa benda berbentuk } \\
\text { balok, seperti: kotak pasta gigi dan } \\
\text { kotak sabun. } \\
\text { 3. Menggunting kotak pasta gigi dan } \\
\text { kotak sabun sehingga nampak } \\
\text { jaring-jaring balok dan } \\
\text { menempelnya di papan tulis. } \\
\text { 4. Meminta siswa untuk menggambar } \\
\text { jaring-jaring balok secara mandiri } \\
\text { sesuai dengan strategi masing- } \\
\text { masing. } \\
\text { 5. Mendekati siswa sambil } \\
\text { memberikan bantuan seperlunya. } \\
\text { 6. Menjelaskan secara formal } \\
\text { caramenggambar dan } \\
\text { mengidentifikasi jaring-jaring }\end{array}$ & $\begin{array}{l}\text { 1. Menggali pengalaman masing- } \\
\text { masing dan menyebutkan benda- } \\
\text { benda dalam kehidupan sehari-hari } \\
\text { yang bentuknya menyerupai balok. } \\
\text { 2. Memperhatikan dengan baik alat } \\
\text { peraga yang ditunjukkan guru. } \\
\text { 3. Memperhatikan bentuk kotak pasta } \\
\text { gig dan kotak sabun yang telah } \\
\text { digunting dengan seksama. } \\
\text { 4. Mengerjakannya secara mandiri } \\
\text { sesuai dengan strategi masing- } \\
\text { masing. } \\
\text { 5. Meminta bantuan kepada guru atau } \\
\text { teman apabila mengalami kesulitan. } \\
\text { 6. Mendengarkan dan merumuskan } \\
\text { bentuk matematika formal, yaitu } \\
\text { bentuk matematika yang sering } \\
\text { digunakan dalam proses } \\
\text { pembelajaran di kelas. } \\
\text { 7. Mengerjakan soal-soal dalam LKS. }\end{array}$ \\
\hline
\end{tabular}




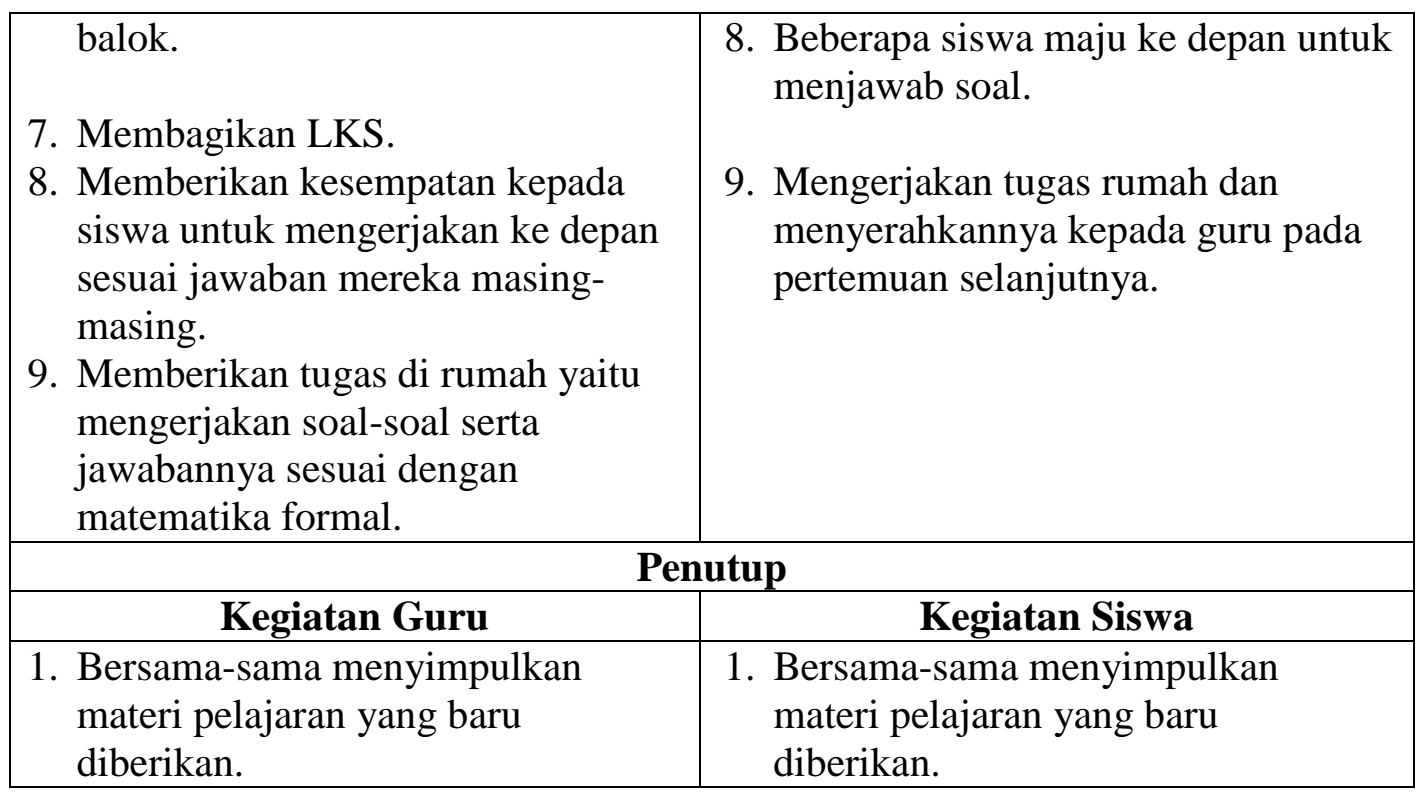

Observasi. Kegiatan observasi dilaksanakan selama proses pembelajaran berlangsung. Observasi terhadap aktivitas belajar siswa dilakukan dengan mengamati prilaku yang tampak menggunakan lembar observasi, sedangkan kegiatan evaluasi dilaksanakan untuk mengetahui prestasi belajar siswa dengan menggunakan tes prestasi belajar pada akhir siklus II.

Refleksi. Refleksi dilakukan berdasarkan hasil observasi dan hasil evaluasi tes prestasi belajar siswayang dilaksanakan pada akhir siklus II. Dari hasil refleksi tersebut akan diketahui apakah terjadi peningkatan aktivitas dan prestasi belajar siswa dalam pembelajaran bangun ruang dengan penerapan pendekatan pembelajaran matematika realistik. Apabila tidak terdapat kendala-kendala yang berarti serta proses pembelajaran telah optimal maka akan dirumuskan rekomendasi penelitian ini berhasil dan siklus dihentikan, jika tidak maka akan dilakukan siklus berikutnya.

\section{Pengecekan Keabsahan Data}

Untuk mengecek keabsahan data dalam penelitian ini digunakan teknik triangulasi, pemeriksaan sejawat melalui diskusi dan konsultasi dengan dosen pembimbing. Triangulasi adalah teknik pemeriksaan keabsahan data yang memanfaatkan sesuatu yang 
lain di luar data untuk keperluan pengecekan atau sebagai pembanding terhadap data itu (Moleong, 2011:330). Teknik pemeriksaan sejawat melalui diskusi dilakukan dengan cara mengumpulkan hasil sementara atau hasil akhir yang diperoleh dalam bentuk diskusi dengan rekan-rekan sejawat.

Dalam penelitian ini, teknik triangulasi dan pemeriksaan sejawat dilakukan melalui diskusi secara terpadu, yang melibatkan dua orang rekan sejawat dan guru mata pelajaran matematika di kelas yang diteliti. Hasil diskusi tersebut dikonsultasikan kepada dosen pembimbing untuk mendapatkan arahan dan revisi bila diperlukan dalam upaya mendapatkan data sesuai dengan derajat keabsahan yang diharapkan.

\section{HASIL PENELITIAN DAN}

\section{PEMBAHASAN}

\section{Hasil Penelitian}

Berdasarkan analisis data aktivitas belajar siswa tiap siklus, maka dapat disajikan hasil analisis data aktivitas belajar siswa seperti yang diuraikan dalam tabel berikut ini.

Tabel 05 Hasil Analisis Data Aktivitas Belajar Siswa

\begin{tabular}{|c|c|c|c|c|}
\hline No. & Siklus & Pertemuan ke- & $\begin{array}{c}\text { Rata-rata Skor } \\
\text { Aktivitas }(\overline{\mathrm{A}})\end{array}$ & Kategori \\
\hline \multirow[t]{3}{*}{1.} & \multirow[t]{3}{*}{$\mathrm{I}$} & 1 & 10,20 & Cukup aktif \\
\hline & & 2 & 12,11 & Cukup aktif \\
\hline & & Rata-rata & 11,155 & Cukup aktif \\
\hline \multirow[t]{3}{*}{2.} & \multirow[t]{3}{*}{ II } & 4 & 13,24 & Aktif \\
\hline & & 5 & 13,67 & Aktif \\
\hline & & Rata-rata & 13,455 & Aktif \\
\hline
\end{tabular}

Berdasarkan analisis data

prestasi belajar siswa tiap, maka dapat disajikan hasil analisis data beserta persentase peningkatannya seperti yang diuraikan dalam tabel 06 dan tabel 07 berikut ini. 
Tabel 06 Hasil Analisis Data Prestasi Belajar Siswa

\begin{tabular}{|c|c|c|c|c|}
\hline No. & Siklus & $\begin{array}{c}\text { Rata-rata } \\
\text { Skor Prestasi } \\
(\overline{\mathrm{X}})\end{array}$ & $\begin{array}{c}\text { Ketuntasan Belajar } \\
(\mathrm{KB})\end{array}$ & $\begin{array}{c}\text { Daya Serap } \\
(\mathrm{DS})\end{array}$ \\
\hline 1. & $\begin{array}{c}\text { Pra- } \\
\text { Siklus }\end{array}$ & 4,98 & $26,67 \%$ & $49,80 \%$ \\
\hline 2. & I & 6,66 & $53,30 \%$ & $66,60 \%$ \\
\hline 3. & II & 8,20 & $91,10 \%$ & $82,00 \%$ \\
\hline
\end{tabular}

Tabel 07 Persentase Peningkatan Prestasi Belajar Siswa

\begin{tabular}{|l|c|c|c|}
\hline \multirow{2}{*}{ Siklus ke Siklus } & \multicolumn{3}{|c|}{ Persentase Peningkatan Prestasi Belajar } \\
\cline { 2 - 4 } & $\begin{array}{c}\text { Rata-rata Skor } \\
\text { Prestasi }(\overline{\mathrm{X}})\end{array}$ & $\begin{array}{c}\text { Ketuntasan } \\
\text { Belajar (KB) }\end{array}$ & $\begin{array}{c}\text { Daya Serap } \\
(\mathrm{DS})\end{array}$ \\
\hline Pra-Siklus ke Siklus I & $33,70 \%$ & $99,85 \%$ & $33,70 \%$ \\
\hline Siklus I ke Siklus II & $23,12 \%$ & $70,92 \%$ & $23,12 \%$ \\
\hline
\end{tabular}

\section{Pembahasan}

Berdasarkan hasil observasi awal di kelas IVA SDN 9 Sesetan tahun pelajaran 2011/2012 diperoleh informasi tentang aktivitas dan prestasi belajar siswa pada pelajaran matematika belum mencapai hasil yang optimal. Hal ini dapat dilihat dari pencapaian rata-rata skor prestasi belajar siswa $(\overline{\mathrm{X}})$ yang masih kurang dari 6,5, ketuntasan belajar (KB) di bawah 85\%, dan daya serap (DS) kurang dari 65\%.

Sebelum pelaksanaan tindakan terlebih dahulu dilakukan prasiklus. Dalam PTK ini, prasiklus dilakukan sebanyak dua kali meliputi: (1) observasi awal, dan (2) pemberian tes prasiklus. Kedua langkah tersebut dilakukan untuk mengetahui aktivitas belajar siswa dan kemampuan belajar awal siswa sebelum pelaksanaan tindakan.Berdasarkan hasil analisis data yang diperoleh dari hasil observasi dan tes prasiklus di dapat informasi tentang aktivitas dan prestasi belajar siswa khususnya pada pelajaran matematika belum mencapai hasil yang optimal. Hal ini dapat dilihat dari aktivitas siswa pada saat proses belajar mengajar berlangsung masih pasif. Selain itu prestasi belajar siswa dilihat dari rata-rata skor prestasi belajar siswa $(\bar{X})$ pada prasiklus $=4,98$, daya serap $(\mathrm{DS})=49,80 \%$, dan ketuntasan belajar $(\mathrm{KB})=26,67 \%$. Kedua hal ini menunjukkan bahwa aktivitas 
belajar siswa dalam mengikuti proses pembelajaran dan prestasi belajar siswa dalam pelajaran matematika khususnya bangun ruang masih rendah.

Berdasarkan hal tersebut maka peneliti melakukan penelitian tindakan kelas dengan menerapkan pendekatan pembelajaran matematika realistik sebagai salah satu upaya untuk meningkatkan aktivitas dan prestasi belajar siswa kelas IVA SDN 9 Sesetan tahun pelajaran 2011/2012.

Berdasarkan hasil analisis data aktivitas siswa pada siklus I diperoleh bahwa aktivitas belajar siswa belum mencapai kategori aktif. Sedangkan hasil analisis data prestasi belajar siswa pada siklus I, juga menunjukkan belum mencapai kriteria keberhasilan minimal. Berdasarkan hasil observasi kegiatan pembelajaran pada siklus I yang ditulis dalam buku catatan lapangan, ditemukan beberapa kendala yang menyebabkan kurang optimalnya pembelajaran pada siklus I, yaitu: (1) ada beberapa siswa yang masih ribut pada saat guru menjelaskan materi, (2) ada beberapa siswa yang kurang aktif dalam diskusi di kelas, (3) siswa yang memiliki kemampuan kurang, malu untuk bertanya kepada guru maupun kepada temannya yang lebih pandai apabila mengalami kesulitan dalam pelajaran, (4) siswa yang pandai mendominasi dalam menjawab pertanyaan guru, (5) guru kurang efektif dalam mengelola kelas sehingga waktu yang tersedia tidak dapat dimanfaatkan dengan efektif oleh guru, (6) pemantauan dan arahan guru kepada siswa saat mengerjakan LKS masih kurang intensif.

Berdasarkan hasil observasi tersebut, dilakukan refleksi dengan rekan sejawat untuk menentukan tindakan yang akan dilakukan dalam memperbaiki pembelajaran selanjutnya. Adapun hasil refleksi pada akhir siklus I akan dijadikan acuan dalam pelaksanaan siklus II, yaitu: (1) memberikan pertanyaanpertanyaan secara lisan dan spontan kepada siswa yang masih ribut untuk memfokuskan perhatian siswa, (2) membimbing siswa yang kurang aktif dalam berdiskusi dan menanyakan permasalahan yang sedang dihadapi dalam melakukan 
diskusi, (3) menunjuk siswa yang kemampuannya kurang dan malu bertanya untuk menjawab pertanyaan yang diberikan guru kemudian memberi nilai sebagai motivasi, (4) menunjuk siswa yang kurang aktif dalam diskusi di kelas sehingga tidak didominasi oleh siswa yang pandai saja, (5) guru lebih efektif melakukan pengelolaan kelas sehingga tidak kekurangan waktu, (6) guru lebih intensif dalam memberikan arahan dan bimbingan kepada siswa saat mengerjakan LKS.

Pada tahap observasi dalam siklus II, peneliti bersama guru mengamati dampak dari perbaikan tindakan berdasarkan hasil refleksi siklus I. Berdasarkan penyempurnaan pelaksanaan tindakan pada siklus II dan dari hasil observasi diperoleh bahwa secara keseluruhan siswa terlihat antusias dalam mengikuti kegiatan pembelajaran dan guru sudah bisa mengubah suasana pembelajaran menjadi kondusif dan tidak tegang lagi sehingga siswa sudah merasa senang dalam mengikuti pelajaran matematika di kelas. Hasil observasi pada siklus II ini menunjukkan bahwa perbaikan yang telah dilakukan sudah cukup berhasil. Hal ini dapat dilihat dari hasil analisis data aktivitas belajar siswa yang sudah mencapai kategori "aktif" dengan peningkatan rata-rata skor aktivitas belajar siswa dari siklus I ke siklus II sebesar 20,62\%. Hasil analisis data prestasi belajar siswa pada siklus II telah memenuhi kriteria keberhasilan minimal. Berdasarkan hasil analisis data dan observasi pada siklus I dan siklus II menunjukkan adanya peningkatan aktivitas dan prestasi belajar matematika siswa setelah penerapan pendekatan pembelajaran matematika realistik

Mengacu pada bab III, bahwa pembelajaran dikatakan optimal apabila aktivitas belajar siswa telah mencapai kategori aktif, rata-rata skor prestasi belajar siswa $(\overline{\mathrm{X}}) \geq 6,5$, ketuntasan belajar $(\mathrm{KB}) \geq 85,00 \%$, dan daya serap (DS) $\geq 65,00 \%$. Berdasarkan hasil analisis data yang diperoleh pada siklus II, maka pembelajaran pada siklus II dapat dikatakan telah optimal karena memenuhi kriteria pembelajaran minimal yang telah ditetapkan. Oleh 
karena pembelajaran telah optimal dan hasil yang dicapai pada siklus II ini telah memenuhi tuntutan kurikulum yang berlaku di kelas IVA SDN 9 Sesetan, maka penelitian ini dihentikan sampai pada siklus II.

Dengan demikian, pelaksanaan penelitian tindakan kelas yang difokuskan

dalam penerapan pendekatan pembelajaran matematika realistik sebagai upaya meningkatkan aktivitas dan prestasi belajar siswa dalam pembelajaran bangun ruang pada siswa kelas IVA SDN 9 Sesetan tahun pelajaran 2011/2012 dapat dikategorikan berhasil.

\section{PENUTUP}

\section{Simpulan}

Berdasarkan hasil analisis data dan pembahasan, maka dapat disimpulkan sebagai berikut.

1) Terjadi peningkatan aktivitas belajar siswa kelas IVA SDN 9 Sesetan tahun pelajaran 2011/2012 dalam pembelajaran bangun ruang melalui penerapan pendekatan pembelajaran matematika realistik. Hal ini ditunjukkan dengan peningkatan kategori aktivitas belajar siswa dari siklus I yang tergolong pada kategori cukup aktif menjadi kategori aktif pada siklus II.

2) Terjadi peningkatan prestasi belajar kelas IVA SDN 9 Sesetan tahun pelajaran 2011/2012 dalam pembelajaran bangun ruang melalui penerapan pendekatan pembelajaran matematika realistik. Hal ini ditunjukkan dengan persentase peningkatan rata-rata skor prestasi belajar siswa $(\overline{\mathrm{X}})$, ketuntasan belajar (KB), dan daya serap (DS), dari pra-siklus ke siklus I dan dari siklus I ke siklus II berturut-turut sebesar: $33,70 \%$, 99,85\%, dan 33,70\%; dan 23,12\%, 70,92\%, dan $23,12 \%$.

\section{Saran}

Berdasarkan simpulan tersebut di atas, maka saran yang dapat disampaikan sebagai berikut.

1) Kepada praktisi pendidikan khususnya guru matematika di SDN 9 Sesetan disarankan menerapkan pendekatan pembelajaran matematika 
realistik sebagai salah satu alternatif dalam pembelajaran matematika untuk meningkatkan aktivitas dan prestasi belajar siswa.

2) Kepada Sekolah, disarankan menerapkan pendekatan pembelajaran matematika realistik sebagai salah satu model pembelajaran yang inovatif untuk meningkatkan mutu pembelajaran dan prestasi sekolah khususnya di bidang akademik.

3) Kepada peneliti lain, diharapkan untuk senantiasa melakukan penelitian lebih lanjut dalam pembelajaran matematika baik di sekolah yang berbeda atau pada pokok bahasan yang berbeda sehingga aktivitas dan prestasi belajar siswa dapat terus ditingkatkan.

\section{DAFTAR PUSTAKA}

Lemik, Ni Made. (2010). Pengaruh pendekatan pembelajaran realistik terhadap prestasi belajar matematika siswa sekolah dasar ditinjau dari kemampuan numeric (eksperimentasi pembelajaran pecahan pada siswa-siswa SD di gugus ki hajar dewantara).Tesis tidak diterbitkan. Singaraja: Program Pascasarjana Universitas Pendidikan Ganesha.

Moleong, Lexy J. (2011). Metodologi penelitian kualitatif edisi revisi. Bandung: PT Remaja Rosdakarya.

Nurkancana, I Wayan dan Sunartana, PPN. (1992). Evaluasi hasil belajar. Surabaya: Usaha Nasional.

Soedjadi. (2001). Pemanfaatan realitas dan lingkungan dalam pembelajaran matematika. Makalah disajikan dalam Seminar Nasional Realistic Mathematics Education (RME), FMIPA UNESA, Surabaya, 24 Februari.

Suandhi, I Wayan. (2006). Penelitian tindakan kelas (classroom action research). Diktat Tidak Diterbitkan.Fakultas Keguruan dan Ilmu Pendidikan. Universitas Mahasaraswati.

Suharta, I Gusti Putu. (2001). Pembelajaran pecahan dalam matematika realistik. Makalah disajikan dalam Seminar Nasional Realistic Mathematics Education (RME), FMIPA UNESA, Surabaya, 24 Februari.

Widiyanti, Ida Ayu Putu. (2009). Meningkatkan prestasi belajar matematika siswa 
I Gusti Ayu AristaWidari, I Gusti Ngurah Nila Putra, I Kketut Suwija

dengan penerapan pendekatan pembelajaran matematika realistik dalam materi operasi penjumlahan dan pengurangan bilangan pecahan pada siswa kelas IV SDN 1 angantaka abiansemal tahun pelajaran 2008/2009. Skripsi tidak diterbitkan.Denpasar Fakultas Keguruan dan Ilmu Pendidikan Universitas Mahasaraswati.
Wijaya, Ariyadi. (2012). Pendidikan matematika realistik: suatu alternatif pendekatan pembelajaran matematika. Yogyakarta: Graha Ilmu. 